\title{
57. The effect of family characteristics on communication apprehension during online EFL courses in the Covid-19 remote education period
}

\section{Emrah DOLGUNSÖZ1}

\begin{abstract}
APA: Dolgunsöz, E. (2021). The effect of family characteristics on communication apprehension during online EFL courses in the Covid-19 remote education period. RumeliDE Dil ve Edebiyat Araştırmaları Dergisi, (23), 911-923. DOI: 10.29000/rumelide.953846.
\end{abstract}

\begin{abstract}
The covid-19 pandemic has caused a dramatic transformation in education systems in which faceto-face education was canceled to protect public health in many countries. Homes of the learners turned into classrooms and families have found themselves in the middle of formal education more than ever before. This study aimed to examine the effect of family size on English as a Foreign Language (EFL) communication apprehension (CA) during online foreign language courses. 223 learners of EFL participated in the quantitative part while 37 learners were interviewed for the qualitative procedures. The initial quantitative results indicated a low to moderate oral participation rate in the online EFL courses. The further quantitative findings showed that the number of members in a family predicted CA in online language courses. In the second part of the study, the qualitative results revealed that younger members of the family interrupted the online courses most. Other distractors related to family life were external noises (i.e. guests, street noise) and domestic responsibilities (i.e. cooking, cleaning, working). Parents and elder members of the family were found to have a minimal effect on CA during online courses. The results were discussed in terms of remote education, family, and CA along with pedagogical implications.
\end{abstract}

Keywords: Emergency remote education, EFL, communication apprehension, family

\section{Covid-19 uzaktan eğitim sürecinde çevrimiçi İngilizce dersleri sırasında aile özelliklerinin iletişim kaygısı üzerindeki etkisi}

\section{$\ddot{\mathbf{O z}}$}

COVID-19 salgını, birçok ülkede halk sağlığını korumak için yüz yüze eğitimin iptal edildiği eğitim sistemlerinde ciddi bir dönüşüme sebep olmuştur. Bu dönüşümle birlikte öğrencilerin evleri birer sınıf haline geldi ve aileler kendilerini daha önce hiç olmadı̆̆ı kadar örgün eğitimin ortasında buldular. Bu çalışma, çevrimiçi yabancı dil dersleri sırasında aile birey sayısının Yabancı Dil Olarak İngilizce (EFL) iletişim endişesi (CA) üzerindeki etkisini incelemeyi amaçlamaktadır. Nicel kısma 223 öğrenci katılırken, nitel prosedürler için 37 öğrenci ile yarı yapılandırılmış görüşmeler yapılmıştır. İlk nicel bulgular, çevrimiçi İngilizce derslerinde düşük ila orta düzeyde sözlü katılım oranı olduğunu göstermiştir. Diğer nicel bulgular ise, bir ailedeki üye sayısının çevrimiçi İngilizce derslerindeki iletişim endişesine etki ettiğini ortaya koymuştur. Araştırmanın ikinci bölümünde ise, elde edilen nitel bulgular çevrimiçi İngilizce dersler esnasında öğrencilerin en çok ailenin en küçük bireyleri tarafından rahatsız edildiklerini ortaya çıkarmıştır. Aile hayatıyla ilgili diğer rahatsızlıklar ise dışarıdan gelen gürültüler (konuklar, sokak gürültüsü vb.) ve ev içi sorumluluklardır (yemek

Dr. Öğr. Üyesi, Bayburt Üniversitesi, Eğitim Fakültesi, Yabancı Diller Eğitimi Bölümü, İngiliz Dili Eğitimi ABD (Bayburt, Türkiye), edolgunsoz@gmail.com, ORCID ID: 00oo-0002-1277-2177 [Araștırma makalesi, Makale kayıt tarihi: 12.04.2021-kabul tarihi: 20.06.2021; DOI: 10.29000/rumelide.953846], ETİK: Bayburt Üniversitesi Etik Kurulu, 26.02.2021, 2021/47.

RumeliDE Dil ve Edebiyat Arasttrmaları Dergisi Osmanağa Mahallesi, Mürver Ciçeği Sokak, No:14/8 Kadıköy - ISTANBUL / TÜRKIYE 34714 e-posta: editor@rumelide.com tel: +90 $5057958124,+902167730616$
Address

RumeliDE Journal of Language and Literature Studies

Osmanağa Mahallesi, Mürver Çiçeği Sokak, No:14/8

Kadıköy - ISTANBUL / TURKEY 34714

e-mail: editor@rumelide.com

phone: +90 $5057958124,+902167730616$ 
The effect of family characteristics on communication apprehension during online EFL courses in the Covid-19 remote education period / E. Dolgunsöz (pp. 911-923)

pişirme, temizlik, iş vb.). Ebeveynlerin ve yaşça büyük üyelerin çevrimiçi İngilizce derslerde iletişim endişesine pek fazla etkisi olmadığı göülmüştür. Sonuçlar, pedagojik çıkarımlarla birlikte uzaktan eğitim, aile ve iletişim endişesi açısından tartışılmıştır.

Anahtar kelimeler: Acil uzaktan eğitim, yabancı dil olarak İngilizce, iletişim kaygısı, aile

\section{Introduction}

Recently, the Covid-19 outbreak caused an obligatory transformation in education systems. On a global scale, educational institutions had to cancel face-to-face formal education and had to adopt a brand-new online education system. This new pedagogical practice was called "emergency remote education" (ERE) (Hodges et. al., 2020) in which formal institutions carried on their curricula, syllabi, and weekly class hours on online platforms. Indeed, online education is not a new pedagogy, but remote education is a different form of online education that is applied in emergencies. Due to its emergent nature, remote education is less organized and less well-designed when compared to regular distant education practice. ERE is continuing and unfortunately, a deadline is unpredictable. In this period, foreign language learning is one of the most affected fields of education; in this context, it is learning English as a foreign language (EFL). EFL success requires pure communicative practice and proficiency comes with practice and social interaction. Instead of the advantages of face-to-face classroom practice, EFL learners are now experiencing several disadvantages of ERE. One of these drawbacks is attending online courses from their homes in which they live with other family members. In this extraordinary context, it is still unclear how family life and online language pedagogy interact. Especially in crowded families, learners were thought to suffer from lacking a private room or intervention of family members during online EFL courses. This study aimed to explore the effect of family size on communication apprehension (CA) which would easily affect active classroom performance. Since Covid-19 persists without a certain deadline, the current study was significant as the results might reveal valuable insights on family life and online EFL learning success.

\section{Communication apprehension in foreign language education}

Anxiety refers to the common subjective feeling of uneasiness, discomfort, and worry often manifesting itself with some physiological symptoms such as muscular tension, fatigue, and restlessness (American Psychiatric Association, 2013). In this respect, foreign language anxiety (FLA) can be defined as a specific type of general anxiety that emerges in a foreign language learning context (Brown, 2007). The consensus was that FLA caused low foreign language learning performance and success (MacIntyre, 1999; Horwitz, 2001). According to the affective filter hypothesis, a filter is raised in learner's minds that blocks linguistic input in the case of FLA (Krashen, 1982). One of the most common constructs of FLA is communication apprehension (CA). In general, CA emerges during or before the communication with other people which deteriorates social interaction (Beatty and Andriate, 1985). As a component of FLA, CA also emerges in foreign language communication which shows itself with the unwillingness to communicate, nervousness while communicating in a foreign language, and avoiding to communicate in a foreign language (Jung and McCroskey, 2004; Lucas, 1984).

CA plays an important role in the foreign language classroom environment due to its debilitating effects. CA directly affects classroom performance and participation in foreign language lowering the rate of classroom participation and success (Aida, 1994; Onwuegbuzie et al., 2000; Saito, 1996). CA

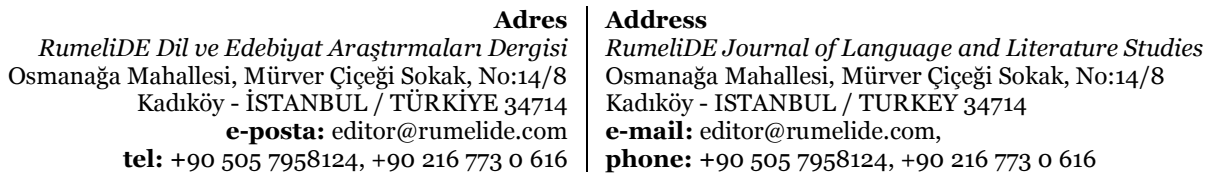


interferes with comprehension and production of a foreign language by disrupting language learning gains and causing slow progress. Language learners suffering from CA commonly avoid communication, do not actively participate during courses, and feel nervous when they are required to communicate in a foreign language (MacIntyre and Charos, 1996; Cheng, Horwitz and Schallert, 1999). CA under the FLA umbrella has been a popular topic of research for decades; however, we still do not have abundant evidence of how CA manifests itself in online platforms. Especially in the Covid19 period, research on CA in the EFL setting is obligatory since FLA was proven to emerge in online educational contexts (Russell, 2018). Underlying reasons of CA vary, but in ERE, this study hypothesized that family characteristics might be a factor that may amplify foreign language CA since learners attend online courses from their homes in which they live with several other family members. This study aims tofind answers for the following research questions:

1. What is the online course participation rate, CA levels, and family size of EFL learners? Does family size predict CA levels?

2. What are the opinions of EFL learners on family size and their online EFL classroom performance and success?

\section{Method}

\section{Design}

An explanatory sequential design was adopted for this study in which quantitative data collection and analysis were followed by the qualitative procedures which were used to explain the initial quantitative results (Creswell and Clark, 2011). This design was suitable for the current research since CA in ERE online EFL courses is quite a new and unknown field. Therefore, initially obtaining quantitative data and then examining these findings through semi-structured interviews was preferred for more reliable data.

\section{Participants}

223 EFL undergraduates (80 males, 133 females) in English Language Departments in three different state universities voluntarily participated in the quantitative part of the study. The age range of the participants was between 18 to 26. All students were attending online courses from their homes for nearly a year due to the Covid-19 pandemic.

Out of 223 participants, 40 learners whose family size and CA levels were above average were invited for the semi-structured interview. 37 of them (27 women, 10 men) accepted the invitation and voluntarily participated in the interviews.

\section{Instruments}

The quantitative part of this study relied on Foreign Language Classroom Anxiety Scale (FLCAS) by Horwitz, Horwitz and Cope (1986). This 5-point Likert scale was known as the most common instrument for measuring FLA due to its popularity, reliability, and practicality (Aida, 1994; Horwitz et al., 1986; MacIntyre, 1999; Arnold, 2007). The scale consisted of 33 items and 3 main constructs as communication apprehension, fear of negative evaluation, and test anxiety. Since the current study aimed to examine CA only, the entire scale was not administered but rather 19 items related to CA

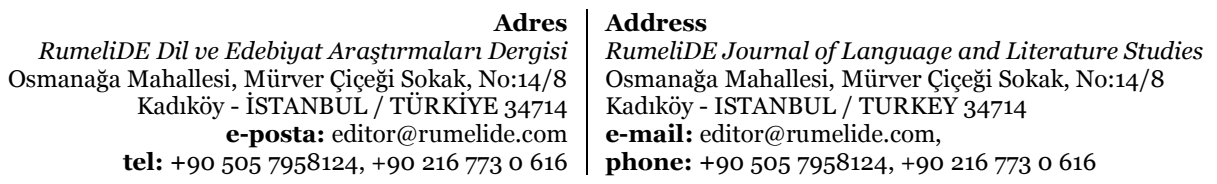


were applied. 19 items related to CA were previously administered by Arnold (2007) and yielded successful results. The same items were also used for this study (see Appendix 2). The entire FLCAS was originally developed in English for American culture and has been translated into several languages for participants from different cultures to avoid any misunderstanding which is an advised practice (Horwitz, 2016). For this study, 19 items related to the CA component were translated into Turkish in blind sessions by 3 translators. The translated versions were later compared and unified. The translated version was piloted to 10 students to ensure validity. The scale was administered online in the participants' native language due to Covid-19 restrictions.

The qualitative procedure included a semi-structured interview. The interview questions were prepared in accordance with the possible effect of family size on course participation and CA. The questions included general questions about family life and members, room availability at home, and house comfort during online courses (see Appendix 1 for interview questions). The interviews were also online and recorded due to Covid-19 restrictions. It was conducted in the native language of the participants.

\section{Data analysis}

Mean CA levels, family size, and participation rates were analyzed via descriptive statistics. The effect of family size on CA levels was examined through simple linear regression. Simple linear regression can be defined as an extended form of correlation that allows the investigation of the relationship between two continuous variables and to examine the predictive effect of an independent variable on the dependent variable (Matthews, 2014). It was adopted for this study since the predictive effect of family size on CA was the main focus of the current study.

For the analysis of the qualitative data, the recorded interviews were transcribed verbatim by the researcher(s). A content analysis was administered to determine the themes. The 6-step thematic analysis method was adopted in the content analysis: (1) Repeated readings were made by the interviewer and the coder. (2) A basic code list was prepared depending on the "family size" theme. (3) Relationships between codes were determined. (4) The transcriptions were examined for participant quotations. (5) The relationships between the theme and codes were determined. (6) The findings were presented in the form of an informative narrative.

\section{Findings}

Quantitative Findings: Participation rate, CA and Family Size

We initially asked learners about their online classroom active participation rates. Figure 1 below illustrated the results.

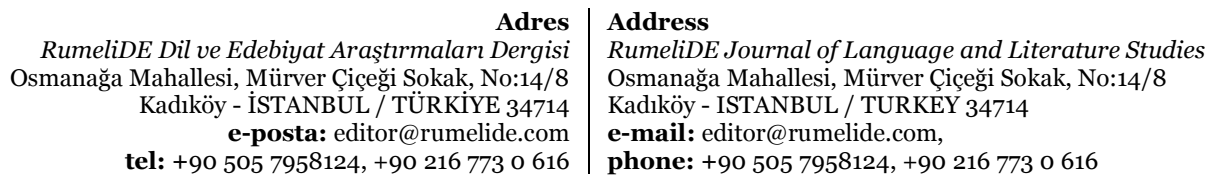

tel: +90 505 7958124, +90 2167730616 


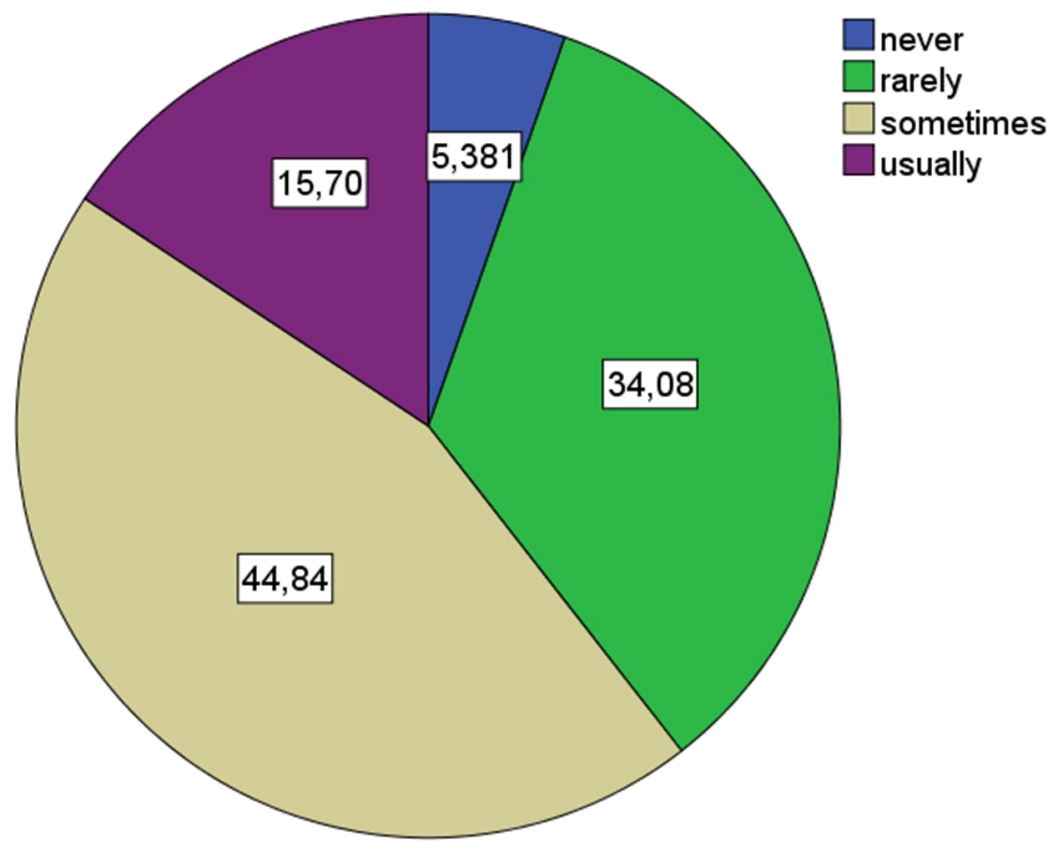

Figure 1. Online Classroom Participation Rates

The results showed that only around $16 \%(\mathrm{~N}=35)$ of the participants usually participated and spoke English during the online EFL courses. Nearly half of the learners $(45 \%, \mathrm{~N}=100)$ mentioned that they participated sometimes. $34 \%$ of the participants $(\mathrm{N}=76)$ reported that they rarely participated and spoke English during the courses. Only 5\% $(\mathrm{N}=12)$ of the learners never participated. Depending on these initial findings, it could be inferred that course participation rates were not high; most learners preferred to stay silent and to speak English only when needed or asked during online English courses.

Secondly, confirming the "moderate to low" participation rates, descriptive findings showed that the mean CA level was $59.4(\mathrm{SD}=18.1)$ which was slightly above average (57). Mean family size was also found to be 4,58 ( $\mathrm{SD}=1.43)$. Depending on these findings, most participants were remaining silent in most of the courses with a CA level above average and had a slightly larger family than a normal elementary family of four members. Hence, it was hypothesized that family size might be a factor increasing CA levels and lowering learner participation rates. To see any predictive effect of family size on CA levels, a simple linear regression was adopted.

Thirdly, the results of the Pearson correlation indicated that there was a significant positive association between family size and CA levels, $\mathrm{r}(223)=.142, \mathrm{p}=.034)$. A simple linear regression was calculated to predict CA levels based on the family size. A significant regression equation was found $(\mathrm{F}(1,221)=4.575, \mathrm{p}=.034)$, with an $\mathrm{R}^{2}$ of .020. Participants' CA level was found to have increased by 1.79 points for each additional family member. To illustrate, 5 additional family members had the potential to increase CA by around 9 points.

Quantitative findings showed that participants mostly remained silent and did not speak English sufficiently during the online courses. They generally had medium-sized families and a CA level slightly above average. Regression results indicated a significant effect of family size on CA levels. Although this effect was not large as expected, family size could be regarded as a factor besides many

\footnotetext{
RumeliDE Dil ve Edebiyat Araştırmalar Dergisi Osmanağa Mahallesi, Mürver Ciceği Sokak, No:14/8 Kadıköy - ISTANBUL / TÜRKIYE 34714 e-posta: editor@rumelide.com

Address

RumeliDE Journal of Language and Literature Studies Osmanağa Mahallesi, Mürver Çiçeği Sokak, No:14/8

Kadıköy - ISTANBUL / TURKEY 34714

e-mail: editor@rumelide.com,

tel: +90 $5057958124,+902167730616$

phone: +90 505 7958124, +90 2167730616
} 
The effect of family characteristics on communication apprehension during online EFL courses in the Covid-19 remote education period / E. Dolgunsöz (pp. 911-923)

other CA factors. For a deeper analysis, family size as a predictor of CA was examined with qualitative procedures.

Qualitative Findings: Family Size and CA during Online EFL Courses

The analysis of the semi-structured interview revealed 3 major categories related to family size. At home, the learners were reluctant to turn on their mics and participate in the online course mainly due to house issues (external distractors), distraction by family members (internal distractors), and domestic responsibilities. Table 1 below showed frequencies and percentages related to these categories and codes.

Table 1. Major Problems at home

\begin{tabular}{|c|c|c|}
\hline Problems & $f$ & $\%$ \\
\hline House issues & 17 & 45,9 \\
\hline External Noise from neighbors, street and surroundings & 6 & 16,2 \\
\hline Guests & 7 & 18,9 \\
\hline Room problems & 4 & 10,8 \\
\hline Distraction by Family Members & 36 & 97,2 \\
\hline Younger siblings & 17 & 45,9 \\
\hline Elder siblings & 2 & 5,4 \\
\hline Device sharing problems & 6 & 16,2 \\
\hline Overlapping online courses & 8 & 21,6 \\
\hline Parents & 1 & 2,7 \\
\hline Elder relatives & 2 & 5,4 \\
\hline Domestic responsibilities & 19 & 51,3 \\
\hline $\begin{array}{l}\text { Housework, cooking, } \\
\text { cleaning, shopping }\end{array}$ & 16 & 43,2 \\
\hline Working to support the family & 3 & 8,1 \\
\hline
\end{tabular}

According to Table 1, during online courses, the learners reported that they were most disturbed by distraction or noise caused by family members. It was followed by domestic responsibilities such as cleaning the house or cooking. House issues such as environmental noises or incoming guests were least effective in engaging oral communication during online courses. About external noises regarding house issues, participants commented:

We live on the second floor. Our house is very close to the street and it looks to the street. There are constant car noises and voices of people. It is disturbing (S14, translated by the author).

Our apartment is a bit crowded and there is a constant noise level, I am a little afraid of speaking during courses. Our upper neighbor is always making a lot of noise (S17, translated by the author).

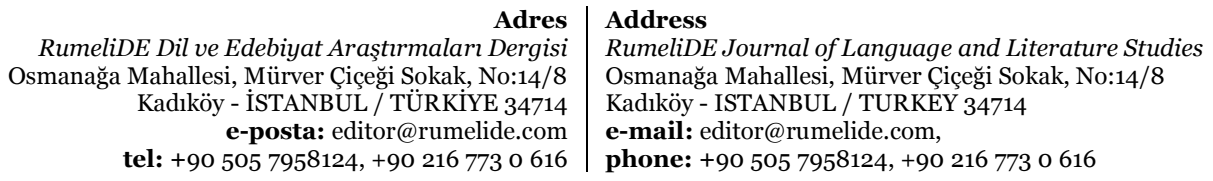


Participants also commented on guests and room problems in the house:

Many guests frequently come to our house... my phone does not connect internet in other rooms, and the guests usually sit in the room where I can connect internet... when guests come, I don't talk in online courses, I just listen (S5, translated by the author).

There is a lot of noise in the house. Thanks to our relatives and guests, we are living 10 people at home every day. I always have to warn everybody to turn on my microphone in class. But it doesn't work very well, they keep making noise (P11, translated by the author).

I don't have my private room; we share it with my sister. She wakes up late, and when I have early morning classes, I have to be silent all the time not to wake her up (S14, translated by the author).

I am already excited during the lessons, I don't have my private room at home, I have to use the living room... the sounds from other rooms disturb me. It annoys me when someone opens the door, wants to take something from the room. For example, once my mother went in saying something, I just turned off the microphone (S19, translated by the author).

Our qualitative results showed that the participants mostly complained about distractions caused by family members. They were disturbed by the younger siblings most and commented:

For example, my little brothers are very problematic for me. They usually play at home, play with balls or toys, I warn them all the time but they never listen to me. Whenever I am about to turn on my microphones, there are always noises. I turn it off so that my friends won't hear it ( $\mathrm{S}_{5}$, translated by the author).

I have 2 younger siblings with 6 and 2 years old, both of them are very naughty. They usually make too much noise. They even cannot realize I am in an online course (S9, translated by the author)

I have a younger brother. I say "come on, I will attend the online course, please leave me alone." But he is too young to understand. He does not go away. They are constantly making noises and shouting with my other brother. They always keep coming into my room making me nervous during online courses (S13, translated by the author).

Yes, too much ... I have a 5-year-old brother, he is making a lot of noise, he is always next to me, always... he always wants me to take care of him, if not he is shouting, trying to get my attention (S6, translated by the author).

Participants also reported their complaints about device sharing problems and overlapping online courses with other family members:

I don't have a computer, my little brothers use the computer to play games and when I want to use it, they fight and make lots of noise. That's why I always have to attend by phone silently (S2o, translated by the author).

Sometimes we have online courses at the same time as my siblings, we experience confusion with the devices, one of the devices may not have a charge or is broken. Then I miss the lesson or I cannot benefit from the course ( $\mathrm{S}_{3}$, translated by the author).

Both my sister and my brother attend online classes... but they are teachers, not students. We go to the furthest rooms not to hear each other... voices sometimes mix up with each other, I have to talk very quietly at those times (S24, translated by the author).

My mom and dad are teachers... they work online from home and I also have a twin. Sometimes we all access the internet at the same time and the network is slowing down, and my voice lags when I turn on the microphone (S15, translated by the author).

The participants mentioned minor complaints about their parents, elder siblings, and grandparents:

I have my grandmother at home, I have to take care of her, we go to the hospital periodically. Hospital appointments sometimes correspond to my online courses, then I cannot attend. Even if I

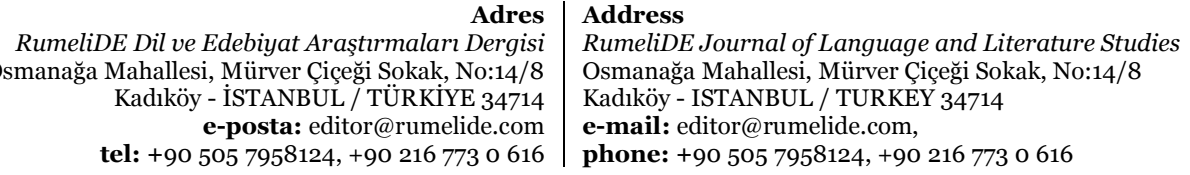


The effect of family characteristics on communication apprehension during online EFL courses in the Covid-19 remote education period / E. Dolgunsöz (pp. 911-923)

attend classes from the hospital, I just listen. I usually forget to listen to the recorded lectures later (S8, translated by the author).

Many participants also commented on their domestic responsibilities and having to work to support the family:

I have responsibilities such as washing, cooking, and cleaning. Sometimes, when there is no time, I attend online courses while cooking, of course, I cannot turn on the microphone. Sometimes when I am at the course, my mother calls me to come to wash the dishes. During the lesson, they sometimes say "heat the food" or "come and prepare the table" (S7, translated by the author).

Housework affects my afternoon lessons very much. My mind is always in the kitchen. In fact, I am more worried that food will not be available during Ramadan. We do it with my mother, but I am generally more active. I have my name on the screen during the classes, but my mind is not there. My mother is not very good at housework (S1O, translated by the author).

The kitchen part of the house is completely on me. My mother and sister are working. I attend morning classes without breakfast. When my brother wakes up, I prepare breakfast for him. In most of the afternoon lessons, I listen to lessons in the kitchen as I prepare the food. Sometimes I attend classes from the kitchen with the microphone, but I'm generally a listener, I do not participate (S16, translated by the author).

We have a small shop next to our house, very close. Most of the time my parents cannot take care of them alone, sometimes I have to go. When I am in the shop, I cannot attend with the microphone, especially the customers come. I'm just listening to the lesson in the shop. I do not connect with the microphone so that the teacher would not ask me to speak because I do not know what to do if the customer comes while I am talking (S12, translated by the author).

I cannot attend online courses much because I work... I go to work in the morning and come back home at around 7:30 pm. I usually try to listen to recorded lectures in the evenings ( $S 34$, translated by the author).

Considering the qualitative findings, it could be proposed that EFL learners most affected by younger members of the family flowed by domestic responsibilities and general house issues.

\section{Discussion}

The results of this study revealed that the obligatory pedagogical transformation due to the Covid-19 pandemic nested several problems regarding family size and student oral EFL performance in online language courses. The initial quantitative findings showed that family size predicted CA in online EFL courses proposing that EFL learners with larger families were reluctant to turn on their microphones and actively participate in English. The further qualitative investigation opened up new components regarding family size. The majority of the participants complained about distractors and noise caused by their younger siblings and overlapping online courses causing device sharing problems. Many participants also mentioned complaints about private room problems, guests, and external noises in the apartment or from the street. Another focus of disturbance was domestic responsibilities such as cleaning, cooking, and working.

In this respect, the quote from Eder (2020, p.169) was significant to mention:

Remote education also necessitates an environment and atmosphere that is conducive to effective teaching and learning. But when living spaces do not allow for some peace and quiet time and family situations (such as forced furlough, unemployment, or caring responsibilities) is an additional stress factor, the quality of education experience could suffer and potentially cause frustration to both learners and educators (p.169).

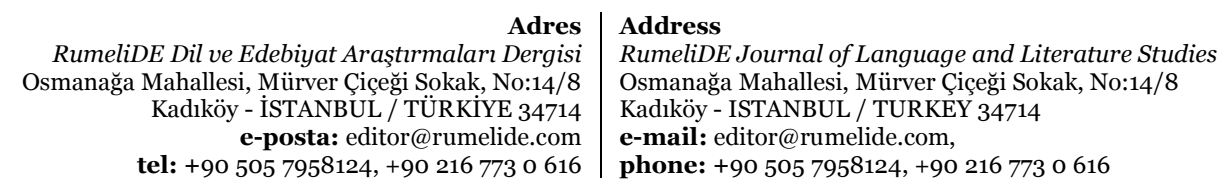

RumeliDE Dil ve Edebiyat Araştırmaları Dergisi -posta: editor@rumelide.com tel: +90 $5057958124,+902167730616$
Address

年 34714

phone: +90 $5057958124,+902167730616$
OumeliDE Journal of Language and Literature Studies 
Firstly, language learners needed an optimized remote education environment to benefit best from online courses. Recent studies on ERE showed that family life was considered as one of the difficulties that emerged in ERE along with fatigue, boredom, internet issues, and the lack of interaction with other students (Dhawan, 2020; Romaniuk and Łukasiewicz-Wieleba, 2020). These emerging and unpredicted ERE difficulties might cause anxiety among learners. The current results confirmed these results indicating that as the distractors at home increased, their anxiety and nervousness also elevated causing them to show unwillingness to participate and communicate in courses. As the number of distractors and noise from outside and inside the house increased, their communication apprehension also increased. According to Tran and Moni (2015), the family was one of the five stakeholders of foreign language anxiety confirming the current findings because an increasing number of family members would naturally increase noise and distractors which learners would not want other students to hear during online courses.

Language instructors should not be mistaken for thinking that communication apprehension did not manifest itself in online settings. The current findings showed that family might be a factor increasing CA along with many other factors in ERE confirming Pichette, 2009 and Russell, 2020 who proposed that online language learners could experience the same high levels of anxiety as face-to-face students in traditional classrooms. Especially in crowded families with several members at school age, communication apprehension elevated as these family members had different pedagogical needs. Intrusions related to family members while online courses were in progress such as parents, spouses, or little children interrupting courses can be found on a video file from St J. D.S.G. Pietermaritzburg (2020). This study revealed that younger family members interrupted language courses most and became the focus of complaints. Problems in sharing a room and devices especially when multiple online courses overlap, language learners had more difficulty in participating in courses and engaging in oral communication. Learners were also found to be more distracted by guests who overpopulate the house during online course times. One interesting positive finding was that elder siblings and parents had minimal effect on communication apprehension. Hence, it could be inferred that parents and elder siblings easily adapted ERE throughout 1 year period.

The final factor inflating CA in online language courses was domestic responsibilities that learners needed to fulfill. These responsibilities were a matter of complaint among the participants who noted that they needed to schedule their time in accordance with these responsibilities. It was not surprising to have these results as TÜIK (2019) reported that the rate of children in the 5-17 age group who helped their families with housework was $45.5 \%$ in Turkey. Furthermore, this proportion was $40 \%$ for males and $51.3 \%$ for females. $43.5 \%$ of this age group were supporting their family with various domestic works such as doing shopping, washing dishes, cleaning, tidying, ironing, cooking, and caring for younger siblings. In this regard, this rate and age might be higher for more crowded families in which parents were working all day and leaving the housework for the elder members. In the context of this study, the learners were not satisfied with this situation emphasizing that this workload caused them to benefit less from online language courses.

\section{Conclusions and pedagogical implications}

The current study aimed to shed light on family issues and online EFL learning during ERE. The findings showed an undeniable effect of family members on course performance and communication apprehension. Considering the current results, several pedagogical implications were as follows:

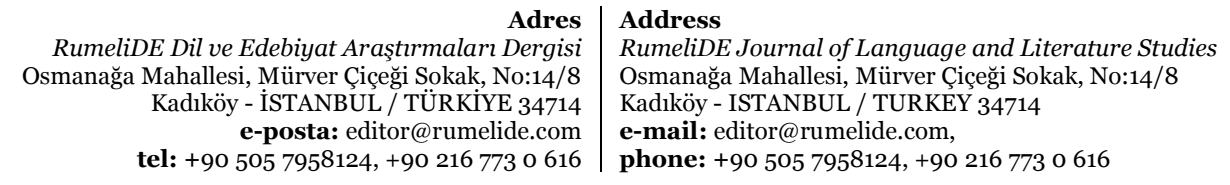

RumeliDE Dil ve Edebiyat Araştırmaları Dergisi , Mürver Çiçegi Sokak, No.14/8 tel: +90 505 7958124, +90 2167730616
Address

Osman

e-mail: editor@rumelide.com,

phone: +90 5057958124, +90 2167730616 
- Language instructors should keep thinking deeper regarding the fact that learners suffering from CA avoid engaging in online classroom activities (Horwitz et al., 1986, p. 131). This becomes more important in the period of ERE since learners may have several intrusions from family members and noise during the online language courses.

- Considering CA triggers at home, language instructors may provide more warm-up activities for learners at the beginning of online courses before learners are required to engage in oral participation. According to Payne (2020), these warm-up activities can help to decrease cognitive load and create a basis for a less anxious environment. Group interaction may also help students overcome their feelings of social isolation and loneliness during the pandemic. Rather than directing questions to learners, instructors may think to encourage small group discussions first and then ask their ideas individually. Group discussions may help learners to suppress CA.

- Instructors may encourage learners to involve in relaxation activities (Horwitz et al., 1986) such as deep breathing exercises accompanied by soft music even during the online courses for a few minutes.

- In case of low classroom participation rate, instructors should avoid searching blame with their course content but should keep in touch with students. During the ERE period, there may be several stressors during online courses. Showing support and encouragement with emails, WhatsApp or any other platforms may help to decrease CA over time as such interactions were proven to be beneficial in the study by Russell and Murphy- Judy (2020). Instructors can also create google classrooms, WhatsApp, or Facebook groups to promote interaction and to provide a student support system in which learners can discuss the online language learning progress.

- Students can be encouraged to register for foreign language learning apps and websites such as Busuu, Mixxer or and Speaky. In this way, learners would practice and cope with their CA outside the online course schedule.

- Finally, instructors should not avoid getting in contact with students and families when it is needed. The instructor's intervention may create a unifying effect on family and increase their awareness during ERE.

\section{References}

Aida, Y. (1994). Examination of Horwitz, Horwitz, and Cope's construct of foreign language anxiety: The case of students of Japanese. Modern Language Journal, 78 (3), 155-168.

American Psychiatric Association (2013). Diagnostic and Statistical Manual of Mental Disorders (Fifth ed.). Arlington, VA: American Psychiatric Publishing. p. 189.

Arnold, N. (2007). Reducing foreign language communication apprehension with computer-mediated communication: A preliminary study. System, 35(4), 469-486.

Beatty, M.J., Andriate, G.S. (1985). Communication apprehension and general anxiety in the prediction of public speaking anxiety. Communication Quarterly, 33 (3), 174-184.

Brown, D. H. (2007). Principles of language learning and teaching. Pearson Education, US

Cheng, Y., Horwitz, E.K., Schallert, D.L., (1999). Language anxiety: Differentiating writing and speaking components. Language Learning, 49 (3), 417-446.

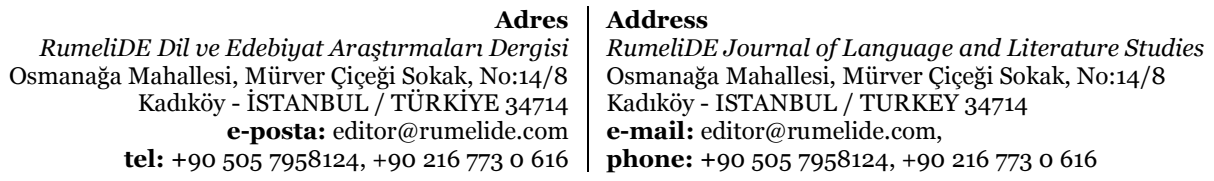


Creswell, J. W., Plano Clark, V. L. (2011). Designing and conducting mixed methods research. Thousand Oaks, CA: Sage.

Dhawan, S. (2020). Online Learning: A Panacea in the Time of COVID-19 Crisis. Journal of Educational Technology Systems, vol. 49, no. 1, pp. 5-22

Eder, R. (2020). The remoteness of remote learning: A policy lesson from COVID19. Journal of Interdisciplinary Studies in Education, 9(1), 168-171.

Hodges, C., Moore, S., Lockee, B., Trust, T., \& Bond, A. (2020). The difference between emergency remote teaching and online learning. Educause review, 27, 1-12.

Horwitz, E.K., (2001). Language anxiety and achievement. Annual Review of Applied Linguistics 21, 112-126.

Horwitz, E. K. (2016). Factor structure of foreign language classroom anxiety scale: Comment on Park (2014). Psychological Reports, 119(1), 71-76

Horwitz, E.K., Horwitz, M.B., Cope, J., (1986). Foreign language classroom anxiety. Modern Language Journal. 70 (2), 125-132.

Jung, H.Y., McCroskey, J.C. (2004). Communication apprehension in a first language and selfperceived competence as predictors of communication apprehension in a second language: A study of speakers of English as a second language. Communication Quarterly. 52 (2), 170-181.

Krashen, S. (1982). Principles and second language acquisition. Oxford, UK: Pergamon.

Lucas, J. (1984). Communication apprehension in the ESL classroom: Getting our students to talk. Foreign Language Annals. 17 (6), 593-598.

MacIntyre, P.D. (1999). Language anxiety: A review of the research for language teachers. In: Young, D.Y. (Ed.), Affect in foreign language and second language learning: A practical guide to creating a low-anxiety classroom atmosphere. McGraw-Hill College, Boston, pp. 24-46.

MacIntyre, P.D., Charos, C. (1996). Personality, attitudes, and affect as predictors of second language communication. Journal of Language and Social Psychology. 15 (1), 3-26.

Matthews, D. E. (2014). Linear regression, simple. Wiley StatsRef: Statistics Reference Online.

Onwuegbuzie, A.J., Bailey, P., Daley, C.E. (2000). Cognitive, affective, personality and demographic predictors of foreign-language achievement. The Journal of Educational Research. 94 (1), 3-15.

Payne, J. S. (2020). Developing L2 productive language skills online and the strategic use of instructional tools. Foreign Language Annals, 53(2), 243-249.

Romaniuk, M. W., \& Łukasiewicz-Wieleba, J. (2020). Crisis remote education at The Maria Grzegorzewska University during social isolation in the opinions of students. International Journal of Electronics and Telecommunications, 807-812.

Russell, V. (2018). Assessing the effect of pedagogical interventions on success rates and on students' perceptions of connectedness online. In S. Link \& J. Li (Eds.), Assessment across online language education (pp. 49-70). Sheffield, UK: Equinox. CALICO Series: Advances in CALL Research and Practice.

Russell, V. (2020). Language anxiety and the online learner. Foreign Language Annals, 53(2), 338352.

Russell, V., \& Murphy-Judy, K. (2020). Teaching language online: A guide to designing, developing, and delivering online, blended, and flipped language courses. New York: Routledge

Saito, Y., 1996. Foreign language anxiety and language performance: A study of learner anxiety in beginning, intermediate, and advanced-level college students of Japanese. Foreign Language Annals. 29 (2), 239-249.

St John's D.S.G. Pietermaritzburg. (2020, April 15). When online teaching goes wrong ... lockdown 2020 [Video file]. https://www.youtube.com/watch?v=3w1sejUgI50

\begin{tabular}{r|l} 
Adres & Address \\
RumeliDE Dil ve Edebiyat Araşttrmaları Dergisi & RumeliDE Journal of Language and Literature Studies \\
Osmanağa Mahallesi, Mürver Çiçeği Sokak, No:14/8 & Osmanağa Mahallesi, Mürver Çiçeği Sokak, No:14/8 \\
Kadıköy - ISTANBUL / TÜRKIYE 34714 & Kadıköy - ISTANBUL / TURKEY 34714 \\
e-posta: editor@rumelide.com & e-mail: editor@rumelide.com, \\
phone: +90 505 7958124, +90 2167730616
\end{tabular}


Tran, T. T. T., \& Moni, K. (2015). Management of foreign language anxiety: Insiders' awareness and experiences. Cogent Education, 2(1), 992593.

Türkiye İstatitik Kurumu. (2020). İstatistiklerle Aile, 2019. Retrieved from https://tuikweb.tuik.gov.tr/PreHaberBultenleri.do?id=33730 in March 19 ${ }^{\text {th }}, 2021$.

\section{Appendices}

Appendix 1. Semi-Structured Interview Questions (Translated)

1. Derselere aktif katılımın nasıl? Kendinizden memnun musunuz?

2. Evde kaç kişi yaşıyorsunuz? Ev yeterince geniş mi? Online derslere nereden katılıyorsunuz? Kendinize ait odanız var mı? Bu durum derse katılımınızı etkiliyor mu? Gürültü olur diye mikrofon açmadığın oluyor mu? Varsa ne gibi rahatsız edici sesler ve gürültüler olabiliyor?

3. Anne ve babanız derse herhangi bir şekilde engel teşkil ediyormu? Derste olduğunuzun farkındalar mı? Yeterince hassasiyet gösteriyorlar mı? Ders esnasında rahatsız edici gürültü yada ses yapıyorlar mi?

4. Kardeşlerin var mı? Onlar da okuyorlar mı? Bu derse katılımınıza herhangi bir engel teşkil ediyor mu? Laptop vs gibi cihazları (varsa) paylaşıyor musunuz? Ne gibi zorluklar olabiliyor?

5. Genel ev rutininiz nasıl? Derslere katılmak dışında ne gibi ekstra görevleriniz ve sorumluluklarınız var ev içinde? Bu durum derse aktif katılımınızı ve motivastonunuzu etkiliyor mu? Rahatça derse girip katılabiliyor musunuz? Diğer aile üyeleri sürekli sizden bir sorumluluk yerine getirmenizi istiyorlar $\mathrm{ml}$ ?

Appendix 2. FLCAS Communication Apprehension with Demographics (Translated)

Evde kaç kişi yaşıyorsunuz?

Kendinize ait bir odanız var mı?

Online derslere hangi oranda söz hakkı alarak aktif katılıyorsunuz ve İngilizce konuşuyorsunuz?

(1) Online İngilizce derslerde İngilizce konuşurken kendimden asla tam olarak emin olamıyorum.

(2) Online İngilizce derslerde hata yapmak beni endişelendiriyor.

(3) Online İngilizce derslerde hoca bana söz hakkı verdiğinde titriyorum.

(4) Hocanın İngilizce ne dediğini anlamamak beni korkutuyor.

(5) Online İngilizce derslerde hazırlıksız ve aniden İngilizce konuşmam gerektiğinde paniğe kapiliyorum.

(6) Online İngilizce derslere katılımım düşük; kendi isteğimle söz hakkı alarak katılmıyorum.

(7) Online İngilizce derslere iyi hazırlanmış olsam bile derste endişeli hissediyorum.

\begin{tabular}{r|l} 
Adres & Address \\
RumeliDE Dil ve Edebiyat Araştırmalar Dergisi & RumeliDE Journal of Language and Literature Studies \\
Osmanağa Mahallesi, Mürver Çiçeği Sokak, No:14/8 & Osmanağa Mahallesi, Mürver Çiçeği Sokak, No:14/8 \\
Kadıköy - İSTANBUL / TÜRKIYE 34714 & Kadıköy - ISTANBUL / TURKEY 34714 \\
e-posta: editor@rumelide.com & e-mail: editor@rumelide.com, \\
phone: +90 505 7958124, +90 2167730616
\end{tabular}


(8) Online İngilizce derslerde İngilizce konuşurken kendime güvenemiyorum.

(9) Online İngilizce derslerde hoca söz hakkı verdiği zaman kalbimin çarptığını hissedebiliyorum.

(10) Her zaman diğer öğrencilerin benden daha iyi İngilizce konuştuğunu düşünüyorum.

(11) Diğer öğrencilerin önünde İngilizce konuşmak beni strese sokuyor.

(12) Online İngilizce derslerde diğer derslerime göre daha gergin hissediyorum.

(13) Online İngilizce derslerde İngilizce konuşurken gerginim ve kafam karışıyor.

(14) Hocanın söylediği her kelimeyi anlamadığım zaman strese giriyorum.

(15) Online İngilizce derslerde İngilizce konuştuğumda diğer öğrencilerin bana gülmesinden korkuyorum.

(16) Anadili İngilizce olanların yanında gergin hissediyorum.

(17) Online İngilizce derslerde hazırlık yapmadığım sorular sorulduğunda strese giriyorum.

(18) Online İngilizce derslerde İngilizce konuşurken kendimi rahat ve stressiz ifade edemiyorum.

(19) Online İngilizce derslerde İngilizce konuşmaktan korkuyorum.

Address

RumeliDE Journal of Language and Literature Studies

Osmanağa Mahallesi, Mürver Çiçeği Sokak, No:14/8

Kadıköy - ISTANBUL / TURKEY 34714

e-mail: editor@rumelide.com

phone: +90 5057958124, +90 2167730616 